\title{
A 249-Year Record of Floods at Appleby in Westmorland, UK
}

\author{
Colin Clark \\ CHRS Shute Lane, Bruton, Somerset, UK \\ Email: colin4chrs@hotmail.com
}

How to cite this paper: Clark, C. (2020). A 249-Year Record of Floods at Appleby in Westmorland, UK. Journal of Geoscience and Environment Protection, 8, 1-17. https://doi.org/10.4236/gep.2020.812001

Received: October 2, 2020

Accepted: December 1, 2020

Published: December 4, 2020

Copyright $\odot 2020$ by author(s) and Scientific Research Publishing Inc. This work is licensed under the Creative Commons Attribution International License (CC BY 4.0).

http://creativecommons.org/licenses/by/4.0/

\begin{abstract}
An analysis of nearly 250 years of flood records on the river Eden at Appleby-in-Westmorland has enabled a flood frequency relationship to be established. The most severe floods were in the late $18^{\text {th }}$ and early $19^{\text {th }}$ century. With such a long history of flooding, some remedial measures would have been expected but the local people have, to some extent, adapted to the flood hazard by means of temporary and permanent flood proofing methods such as a cemented board across a doorway and removable flood boards. These measures were overwhelmed during the 2015 flood, as were the flood gates installed by the Environment Agency in 1998. A higher level of protection from floods at Appleby is called for.
\end{abstract}

\section{Keywords}

Historic Floods, Flood Frequency Analysis, Joint Probability Analysis, Human Responses

\section{Introduction}

Forty years ago, Smith and Tobin (1979) wrote: "as a result of inadequate planning policies and partial alleviation strategies, the responsible authorities have failed to contain the flood hazard". Although improvements have been made in many areas of the UK, Appleby-in-Westmorland justifies the sentiments of Smith and Tobin. Even the greater use of historic flood information (Reed \& Bayliss, 2001) has failed to produce a realistic assessment of the flood hazard, and subsequent meetings organised by the British Hydrological Society (Todd \& Black, 2010), did not lead to much more historical flood frequency analysis. According to the Flood Estimation Handbook (IOH, 1999), this should be regarded with greater respect than other indirect methods. In recent historical flood studies (Williams \& Archer, 1999; Macdonald et al., 2006; Macdonald and Black, 
2010; Macdonald, 2012), all events up to the probable maximum flood (PMF), are rarely considered, which for small catchments are often important for dam safety assessments (Clark, 1999; Clark \& Pike, 2007). With uncertainty playing an increasing role in people's lives, there should be more cross validation of flood frequency estimates. The lack of combining evidence is called into question in this paper, which is a description and analysis of major floods on the river Eden at Appleby from 1771.

\section{The River, Rainfall, and Floods}

The river Eden rises on the steep edge of the Pennine Hills and flows NNW towards Appleby, where it drains a catchment area of $337 \mathrm{~km}^{2}$ (Figure 1). Below the town, the catchment lies in the rain shadow of the Lake District, an area of very high mountain peaks many in excess of 600 masl. The annual rainfall varies from over $2500 \mathrm{~mm}$ in the headwaters to about $900 \mathrm{~mm}$ at Appleby (UKMO, 1977) for the period 1941-1970, whilst for the period 1981-2010, it remains unchanged http://i.imgur.com/r/unitedkingdom/Lps9s0h. Land use is mainly peaty moorland on the high slopes with rough grazing and improved grassland on the lower slopes. With a catchment area of $337 \mathrm{~km}^{2}$, the river is most responsive to long duration rainfall from Atlantic depressions as in 1968 and 2015 (Smith \& Tobin, 1979; Cumbria County Council, 2016). Floods have also been caused by summer convective storms such as in 1855 and 1928, (Carlisle Journal 8/7/1855; Cumberland and Westmorland Herald, 24/8/1828). Most floods are winter events, mainly due to the catchment size and response time of about 7 hours, as shown by gauging station records at Great Musgrave (Cumbria County Council, 2016).

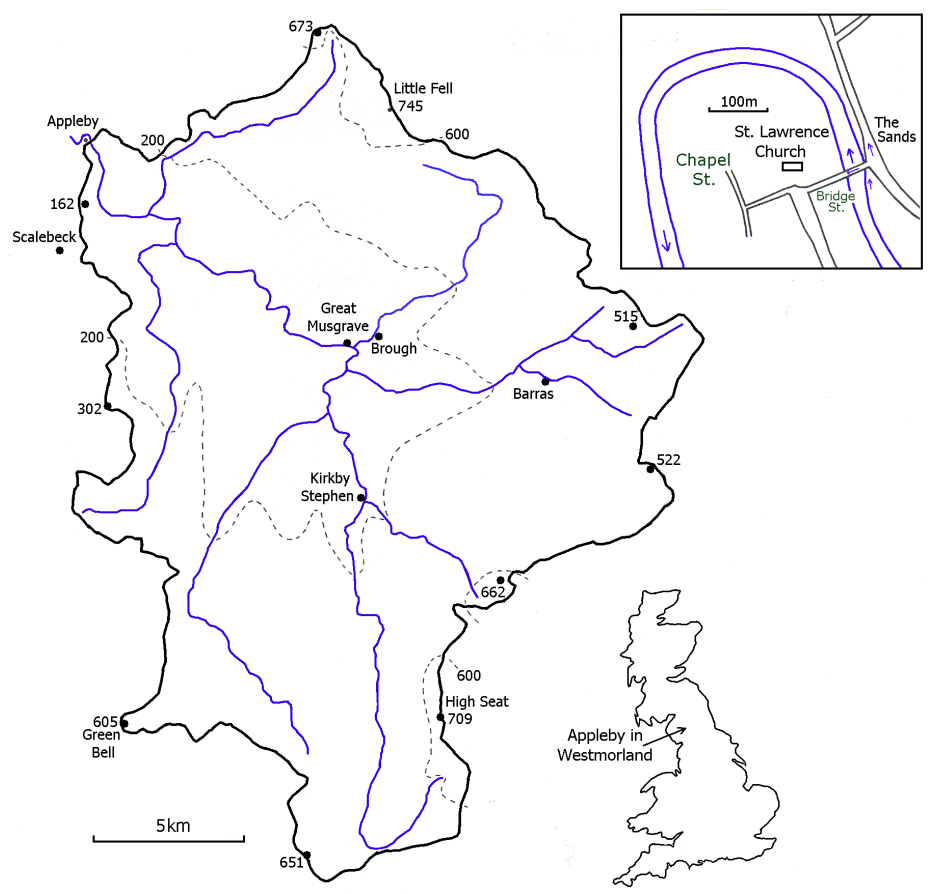

Figure 1. Catchment map and local detail of the river Eden at Appleby. 


\section{Previous Flood Chronologies}

Early studies by Graham Tobin as part of his Ph.D. thesis at Strathclyde University (Glasgow) (Smith \& Tobin, 1979) identified 37 floods since 1815, grouping them into three classes according to their estimated size based largely on newspaper reports. Floods during the $18^{\text {th }}$ century were not considered. The British Hydrological Society website of historical events

(www.dundee.ac.uk/geography/cbhe) reproduces most of this data, but misquotes Mannex (1851) in stating that the water level in 1822 was three feet (0.9 m) in Appleby church: the correct quotation is "In the great flood of 1822, the water was a yard deep both in the church and Rectory House" (Great Musgrave), which is $14 \mathrm{~km}$ upstream of Appleby. More recently, Watkins \& Whyte (2008) gave a list of 34 severe events from a total of about 600 since 1686, covering the whole of the county of Cumbria. Since 2014, Darren Rogers (www.mauldsmeaburnweather.co.uk/floods.htm) has given a list of historic floods, newspaper reports of the serious events and photographs of the recent floods. However, he also identified additional floods not mentioned in Smith \& Tobin (1979) taking place in 1816, 1829, and 1855. The severe flood of 1771 was described by Garret (1818) which marks the start of the present analysis. From the detailed descriptions of the events, the highest floods in chronological order are given in Table 1.

\section{Interpretation of Flood Levels}

The interpretation of the historic flood descriptions depends on an understanding of local conditions, road levels at the time, changes in bridge dimensions, and the relationship between flood levels inside and outside of buildings. Indirect evidence of flow velocities, which are related to flood depth, are also used, for example during the 1771 flood when Garret (1818) reported flagstones in the Cloisters being carried away by the flood waters.

For Appleby four background facts are important. First, the river width has not changed significantly below the town bridge as shown by OS plans in 1971 and 2018. The bridge was rebuilt in 1888. An engraving of the old bridge had been made by Thomas Girton (Figure 2). While the old bridge was narrower

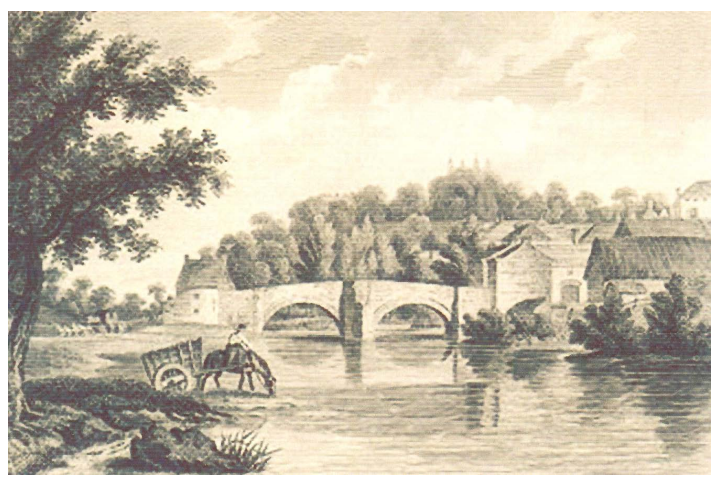

Figure 2. Part of Thomas Girton's engraving of the old bridge at Appleby. 
Table 1. The most severe flood events at Appleby.

\begin{tabular}{|c|c|}
\hline $17 / 11 / 1771$ & $\begin{array}{l}\text { "In houses, it removed dressers, tables \& c... the water ran with a strong current } \\
\text { along Bridge-street, and on the high side of the low cross; it also came down } \\
\text { the church yard, and ran out at the church gates, tore up flags in the cloisters, } \\
\text { and the pavement in the street" (Garret, 1818). }\end{array}$ \\
\hline 29/12/1816 & $\begin{array}{l}\text { "The Eden, at Appleby, Saturday night last was swollen to a greater extent than } \\
\text { has been known for the past fifty years... and though the water ran higher than } \\
\text { the arches it remains unshaken" (Carlisle Patriot } 4 / 1 / 1816 \text { ). "it ran like a torrent } \\
\text { through the streets carrying away with it six carts" (Evening Mail, 8/1/1816). }\end{array}$ \\
\hline $1 / 2 / 1822$ & $\begin{array}{l}\text { "... the water was six feet in depth in the stables of the King's Head inn. Such was } \\
\text { the force of the torrent that the spray rose above the houses like a cloud. Many } \\
\text { houses at the lower end of the town were immersed } 5.5 \text { feet in water" } \\
\text { (Cumberland Pacquet } 11 / 2 / 1822 \text { ). "The water was two feet deep in Appleby } \\
\text { church" (Westmorland Gazette, } 9 / 2 / 1822 \text { ). }\end{array}$ \\
\hline $15 / 2 / 1829$ & $\begin{array}{l}\text { "the river Eden, at Appleby on Wednesday morning was tremendously swollen, } \\
\text { equally in height the flood of February 1822" (Westmorland Gazette 17/2/1829). }\end{array}$ \\
\hline $21 / 8 / 1928$ & $\begin{array}{l}\text { "In Chapel Street where the flood seemed to be worst, the tarmacadam was } \\
\text { ripped off the road by the force of the running water, and houses were flooded } \\
\text { to a depth of four and five feet. The road on The Sands was flooded to the } \\
\text { extent of six feet" (Cumberland and Westmorland Herald, 24/8/1928). } \\
\text { "At Appleby, the water rose to a height of six inches above the flood of } \\
\text { New Years Day 1925" (Carlisle Journal 24/8/1928). }\end{array}$ \\
\hline $24 / 3 / 1968$ & $\begin{array}{l}\text { "Appleby's only chip shop kept on frying until } 9.30 \mathrm{pm} \text { when the water was } \\
\text { lapping around the counter and they were forced to close shop... Even the } \\
\text { Police Station which is about } 4 \mathrm{ft} 6 \text { in above the road was flooded to a depth of } \\
18 \text { in forcing officers to move to an upstairs room. St Lawrence church was } \\
\text { flooded to a depth of } 2 \mathrm{ft} \text { " (Cumberland and Westmorland Herald 30/3/1968). } \\
\text { "About } 250 \text { properties, including } 60 \text { houses and many cars were damaged" } \\
\text { (Cumberland News 29/3/1968). }\end{array}$ \\
\hline $6 / 12 / 2015$ & $\begin{array}{l}\text { This flood caused widespread damage. The church at Appleby was flooded to } \\
\text { a depth of } 2 \text { feet } 2 \text { inches }(0.65 \mathrm{~m}) \text { (Cumbria County Council, 2016). } \\
\text { Great Musgrave Church was flooded to a depth of } 0.59 \mathrm{~m} \text { as compared with } \\
0.91 \text { in } 1822 \text {. Since the main flood response is from the upper two thirds of } \\
\text { the catchment, the flood at Appleby in } 1822 \text { was considerably higher than in } 2015 \text {. } \\
\text { Both flood marks in Great Musgrave church are visible. }\end{array}$ \\
\hline
\end{tabular}

due to a wider cutwater, its arches were higher by about $0.6 \mathrm{~m}$. Second, road levels along the Sands have not risen in the past 150 years or more. Third, the left bank floodplain by St Lawrence Bridge is about $0.8 \mathrm{~m}$ higher than the side occupied by The Sands. Fourth, the water level inside a building, even if poorly fitting doors are present, may not be the same as that outside; for churches whose doors may or may not be closed this adds to the difficulty of interpretation.

The flood of 1822 is probably the highest since the level is stated as being six feet in the stables, which were located on the east side of the Eden. A field survey showed that the floor of these buildings is $127.7 \mathrm{~m}$ OD giving a flood level of $129.53 \mathrm{~m}$ OD. The flood of 1829 was described as being equal in height to that of 1822 and with no other evidence to suggest otherwise must be accepted. The flood of 1771 is clearly a very serious flood but for which no description of the level is given. However from the general damage and the flagstones in the Clois- 
ters being torn up, it has been ranked as the third highest in the record. The flood of 1816 can be interpreted by using the Girton engraving. The soffit level of the old bridge, the appearance of which was engraved by Thomas Girton can be calculated by using a plan dated 1863 which gives the width of the bridge as $30.97 \mathrm{~m}$ By taking measurements directly from the engraving (Figure 2) gives a soffit level of $129.18 \mathrm{~m}$ OD. The flood description tells us that the river ran higher than the arches, but this would have been minimal because of the escape route to the east along The Sands.

The floods of 1928 and 2015 can be distinguished by a consideration of the storm rainfall and flood levels. Table 2 shows that the rainfall intensity was higher in 1928 than in 2015.

The $36 \mathrm{hr}$ depth at South Road, Kirkby Stephen in 1928 was $13 \mathrm{~mm}$ higher than 2015 as shown by the isohyet maps, Figure 3 and Figure 4. For the Eden above Great Musgrave, the areal rainfall for 2015 and 1928 was $68 \mathrm{~mm}$ and 88 $\mathrm{mm}$ respectively. Antecedent soil moisture conditions prior to the storm on $20^{\text {th }}$ August were a zero soil moisture deficit (SMD), with $73 \mathrm{~mm}$ rainfall in July and $86 \mathrm{~mm}$ up until the $20^{\text {th }}$ August at Kirkby Stephen. Soil moisture deficit is crucial to the production of surface runoff. At CHRS there are 34 years' sunken pan data most of which have already been published (Clark, 2013). Relationships have been established between temperature, rainfall and pan evaporation. The values of potential evaporation (PE) measured in an open pan are closely related to evaporation from the weighing lysimeter. $\mathrm{PE}$ is related to rainfall $(\mathrm{R})$ via the following regression equations which are based on 25 years' measurements gathered at CHRS (Clark, 2013).

June $\mathrm{PE}=-0.2802 \mathrm{R}+99.87$.

July $\mathrm{PE}=-0.2141 \mathrm{R}+97.89$.

August $\mathrm{PE}=-0.1088 \mathrm{R}+77.79$.

Table 2. Storm details for 1928 and 2015 floods.

\begin{tabular}{|c|c|c|}
\hline \multirow[b]{2}{*}{1928 storm } & \multicolumn{2}{|c|}{$\begin{array}{c}\text { Average rainfall } \\
\text { intensity }\left(\mathrm{mm} \cdot \mathrm{hr}^{-1}\right)\end{array}$} \\
\hline & & \\
\hline Kirkby Stephen (Redman House) $19^{\text {th }}$ and $20^{\text {th }}$ August: $15.5 \mathrm{~mm}, 110.5 \mathrm{~mm}$ & 0.64 & 4.6 \\
\hline Kirkby Stephen (South Road) 24 hrs ending 1830 hrs; 36 hrs $133.4 \mathrm{~mm}$ & 4.1 & 3.7 \\
\hline Catchment rainfall $20^{\text {th }} 89 \mathrm{~mm}$ & 3.7 & \\
\hline \multicolumn{3}{|l|}{ Storm data from UKMO and Westmorland Gazette, 25/8/1928 } \\
\hline \multicolumn{3}{|l|}{2015 storm } \\
\hline Kirkby Stephen (isohyet map) $4^{\text {th }}$ and $5^{\text {th }}$ December $45.0 \mathrm{~mm}$ and $75.0 \mathrm{~mm}$ & 1.87 & 3.1 \\
\hline Barras $\left(\mathrm{TBR}^{\star}\right) 36.5 \mathrm{~mm}, 46.6 \mathrm{~mm}$, Highest in 23 hours & 2.02 & \\
\hline Kirkby Stephen scaled by rainfall depth: $75 / 46.6 \times 2.02$ & 3.25 & \\
\hline Dale Head (Lake District) highest 24 hours: $105 \mathrm{~mm}$ & 4.37 & \\
\hline Scaled for Kirkby Stephen $75 / 105 \times 4.37$ & 3.12 & \\
\hline \multicolumn{3}{|l|}{ Scalebeck (NY674144) $140.4 \mathrm{~mm}$ in 23 hours; $189 \mathrm{~mm}$ total } \\
\hline Scaled for whole catchment $(75 / 140.4) \times(140.4 / 23)$ & 3.26 & \\
\hline Catchment rainfall $5^{\text {th }}$ December $65 \mathrm{~mm}$ & 2.7 & \\
\hline
\end{tabular}

*TBR Tipping Bucket raingauge. 


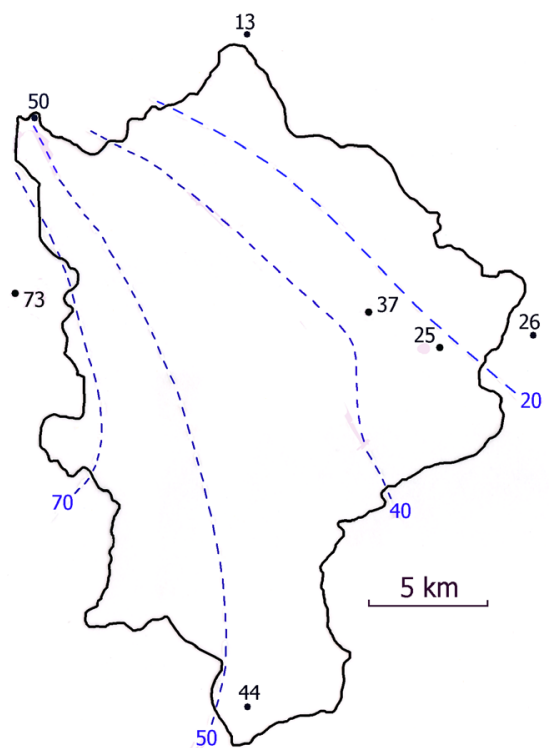

Figure 3. Catchment rainfall for $4^{\text {th }}$ December 2015.

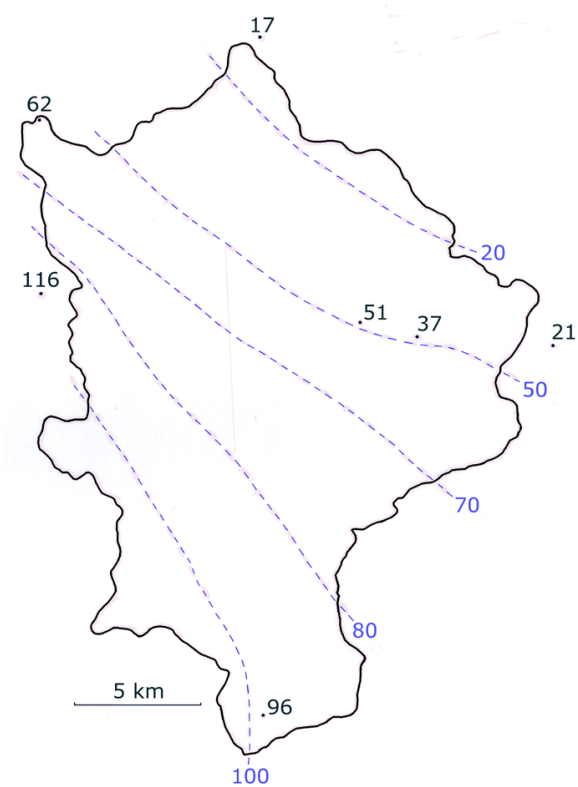

Figure 4. Catchment rainfall for $5^{\text {th }}$ December 2015.

During the early summer rainfall in the upper Eden was much greater than PE with $147 \mathrm{~mm}$ at Appleby; $157 \mathrm{~mm}$ at Kirkby Stephen, and $146 \mathrm{~mm}$ at Stainmore (old gauge). Daily rainfall for July and August until the $20^{\text {th }}$ was then combined with estimates of daily PE to give an estimate of the SMD for $19^{\text {th }}$ August. A summary of the results is shown in Table 3 below.

The 1928 flood level was reported as being $0.15 \mathrm{~m}$ above the New Year flood of 1925, where the water reached the window sills. A field survey along The Sands gave the level as $129.17 \mathrm{~m}$ OD.

For the flood of 2015, the surveyed flood level from the church is in very close agreement with a level given by an eye witness running a business along The 
Table 3. Estimated soil moisture deficit for the August 1928 flood event.

\begin{tabular}{ccccc}
\hline Raingauge & Month & Rainfall & PE mm.day & SMD (mm) \\
\hline \multirow{2}{*}{ Appleby Castle } & July & 88 & 2.55 & 6.8 \\
& August $^{*}$ & 93 & 1.97 & 0.0 \\
Kirkby Stephen & July & 74 & 2.65 & 29.2 \\
& August & 86 & 2.02 & 0.0 \\
Stainmore (old gauge) & July & 75 & 2.63 & 12.2 \\
& August $^{*}$ & 83 & 2.03 & 0.0 \\
\hline
\end{tabular}

NB: PE for August calculated by adjusting rainfall up until the $19^{\text {th }}$ for the whole month: Eg. $(31 / 19) \times 93$ and using the result to calculate PE for the whole month. ${ }^{*}$ Until August $19^{\text {th }}$.

Sands. In the Flood Investigation Report (Cumbria County Council, 2016) the reported flood level is the soffit of St Lawrence Bridge. This stands at $128.68 \mathrm{~m}$ OD but the surveyed level from the wrack mark on the church door is $129.04 \mathrm{~m}$. The difference may be that the peak flow took place at night and could have been missed. Furthermore, the 1968 flood is reported by Smith \& Tobin (1979) as also reaching the bridge soffit at $128.68 \mathrm{~m}$ OD. But residents stated that the 2015 flood was higher than in 1968. A check on this level was based on the newspaper description with $1.83 \mathrm{~m}$ floodwater along The Sands near the Police station. The result was $128.83 \mathrm{~m}$ OD, which needs to be reduced by the water surface slope because this location is above the bridge, to give $128.8 \mathrm{~m}$ OD making the 1968 flood lower than in 2015, in agreement with the statements of residents.

Less severe floods are difficult to distinguish and are therefore not included for analysis. Eye witness reports speak of the river coming to the top of the bank nearly every year, which is an occurrence that would not be reported as a flood. If levels reach nearby properties then an occurrence of about 1 in 3 years would be expected and this compares with 3.5 years (Smith \& Tobin, 1979) and 3 years from the work of Darren Rogers (2019)

(www.mauldsmeaburnweather.co.uk/floods.htm). In comparison, a value of 5 10 years is given by Rogers from a report by the Environment Agency, but the lower limit of 5 years is too high since there have been over 70 reported floods in 200 years. The uncertainty is reduced by the evidence in Figure 5 which is a postcard, posted in 1907 and almost certain to be the flood of $26^{\text {th }}$ January 1903. The tops of the equi-spaced bollards are visible on the left hand side. These are still present and are $0.5 \mathrm{~m}$ high. Calculation of the discharge at this level gives a value of $337 \mathrm{~m}^{3} \cdot \mathrm{s}^{-1}$ which when compared with the flood frequency analysis below, has a return period of about 3 years. From these analyses and comparisons, it is now possible to calculate the flood discharge of the most serious floods.

\section{Calculation of Flood Discharges}

The ranked flood levels allow an estimate to be made of their respective discharges. A field survey of the channel just downstream of St Lawrence Bridge was carried out during the summer of 2019. Two cross sections were surveyed 


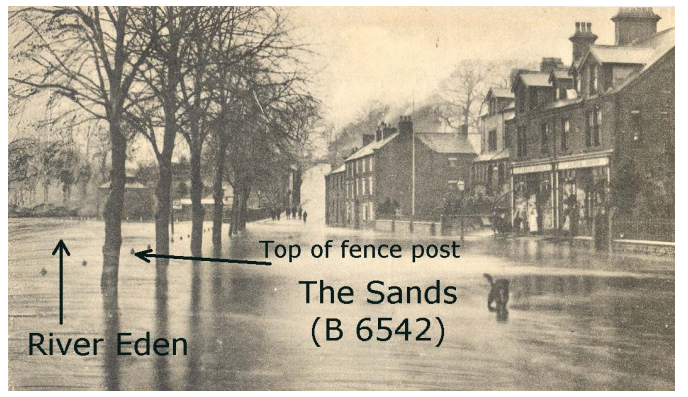

Figure 5. Looking downstream along The Sands in 1907.

one of which is shown in Figure 6. A postcard, which was sent from Appleby in 1903 (Figure 7) looking upstream, shows that the river channel has remained sensibly unchanged for over 120 years. River discharge is calculated using the velocity area method, via the Manning equation:

$Q=V \times A$ where $V=$ velocity, $A=$ cross section area.

$Q=$ discharge, $V=R^{0.666} S^{0.5} n^{-1}$.

where $R=$ hydraulic radius, $S=$ water surface slope, $n=$ Mannings roughness value obtained from (Chow, 1959).

The water surface slope was measured in the field and compared with the value surveyed after the 1968 flood. Field survey between river channel riffles upstream and downstream of St Lawrence Bridge: $1.30 \mathrm{~m}$ in $930 \mathrm{~m}=0.0014$. From Smith \& Tobin (1979), there was a drop of $1.18 \mathrm{~m}$ in $767 \mathrm{~m}=0.0015$. In the present study, the lower value was used.

The $\mathrm{n}$ value was taken as 0.043 which is for a channel "clean, straight, full stage, no deep pools, but with stones and weeds and moderate meandering". More objectively using equation 5.12 (Chow, 1959): $n=$ [material involved $(0.028)+$ degree of irregularity $(0.010)+$ variation in cross section $(0.00)+$ effect of obstruction (0.00) + vegetation (0.005)] $\times$ degree of meandering $(\lambda / L)$ where $\lambda$ = wavelength and $L=$ length of straight reach. In this $=1.00$. Thus $n=0.043$.

Thus: $A=141.5 \mathrm{~m}^{2} . P=49.68 \mathrm{~m}, V=(141.5 / 49.68)^{0.666} S^{0.5} 0.043^{-1}$.

$\mathrm{V}=1.748 \mathrm{~m} \cdot \mathrm{s}^{-1}$.

$Q=1.748 \times 141.5=247 \mathrm{~m}^{3} \cdot \mathrm{s}^{-1}$.

\section{Calculation of Bridge Capacity and the 1822 Flood}

$\begin{array}{lll} & \text { New } & \text { Old } \\ \text { Area }\left(\mathrm{m}^{2}\right) & 52.32 & 46.68 \\ \text { Wetted perimeter }(\mathrm{m}) & 33.28 & 31.23 \\ \text { Water surface slope } & 0.0014 & 0.0014 \\ \text { Mannings } n & 0.02 & 0.02 \\ \text { Discharge (one arch) } & 132.3 & 114.2 \\ \text { Total discharge } & 265 & 228\end{array}$

The estimated discharge for the 1822 flood:

Flood level was $1.78 \mathrm{~m}$ above bankfull discharge. $A=226.05 \mathrm{~m}^{2} . P=53.24$. 


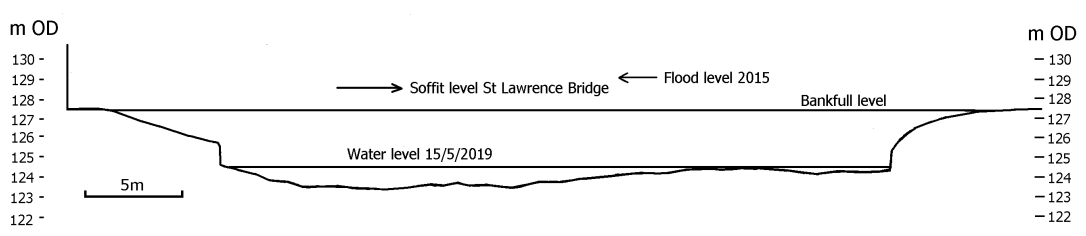

Figure 6. River cross section below St Lawrence Bridge.

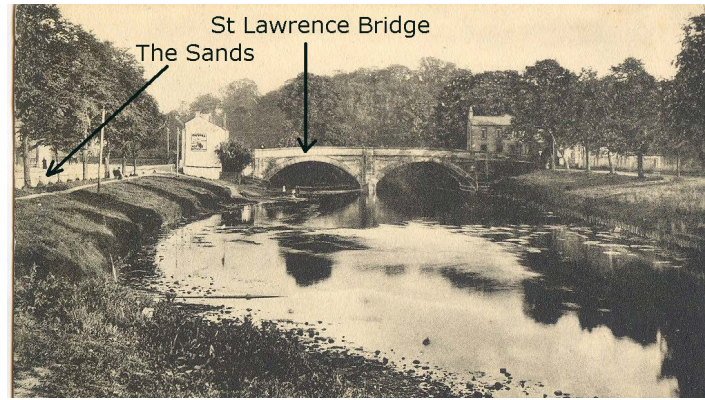

Figure 7. Looking upstream towards St Lawrence Bridge, circa 1900.

$S$ and $n$ as before.

$Q=515.7 \mathrm{~m}^{3} \cdot \mathrm{s}^{-1}$.

Floodwaters also passed along The Sands and Bridge Street (Figure 1). These pathways have a different $n$ value. The water surface slope is assumed to be the same as the main channel.

The Sands: $A=44.5 \mathrm{~m}^{2} . P=28.56 \mathrm{~m} . n=0.025 . S=0.0014$.

$Q=89.5 \mathrm{~m}^{3} \cdot \mathrm{s}^{-1}$.

Bridge Street. Level taken from $128.3 \mathrm{~m}$. Thus flood depth $=1.23 \mathrm{~m} . A=$ 15.48. $P=12.26 . n=0.02$. $Q=33.83$.

Total discharge $=515.7+89.5+33.83=639 \mathrm{~m}^{3} \cdot \mathrm{s}^{-1}$.

Discharge for the remaining floods was calculated and the results are shown in Table 4.

\section{Flood Frequency Analysis}

Flood frequency and rainfall analyses are an inexact science. Land use change can affect flood frequency but for the upper Eden early maps show little if any change in land use especially above Kirkby Stephen where the flood response is generated. Neither have there been any marked changes in monthly rainfall in the region since 1873

(www.metoffice.gov.uk/hadobs/hadukp/data/download.html). Hence the problem of non-stationarity is not significant. However, there are a number of cross checks which can be made. These include an estimate of bankfull discharge, a water balance check of the probable maximum flood (PMF), SMD measurements or calculations, and comparison with the Extreme Catastrophic Flood (ECF) of Allard et al. (1960), which give the user more confidence in the results. Very few historical hydrology studies make estimates of very rare $10^{3}-10^{6}$ year events. The present author's work is an exception (Clark, 2014, 2018) and as a 
Table 4. Estimates of peak discharges of the seven largest floods at Appleby in Westmorland.

\begin{tabular}{cccc}
\hline Year of flood & River level $(\mathrm{m})$ & Peak discharge & Return period \\
\hline 1822 & 129.53 & 639 & 271 \\
$1829^{*}$ & 129.53 & 639 & 271 \\
1771 & 129.34 & 587 & 99 \\
1816 & 129.3 & 577 & 72 \\
1928 & 129.17 & 539 & 57 \\
2015 & 129.04 & 517 & 47 \\
1968 & 128.8 & 488 & 40
\end{tabular}

Note: Return periods calculated on the basis of record length ( 249 years) plus 20 years to make some allowance for the period of record starting with a flood (Reed \& Bayliss, 2001). Return periods calculated using Clark (1983) $\mathrm{Rp}=\mathrm{N} /(\mathrm{M}-0.3)$ where $\mathrm{N}=$ number of years' record, $\mathrm{M}=$ rank order of the flood. Return periods plotted on a modified Gumbel scale (Clark, 2015). *The levels of the 1822 and 1829 floods are given as the same. Therefore the return period is estimated as being the average of 384 and 158 years had they been different: viz. $(249+20) /(1-0.3)=384$ years. $(249+20) /(2-0.3)=158$ years.

result of the estimates of the PMF at Bruton flood detention reservoir in Somerset UK based on historic flood analysis, which was also backed up by new estimates (Clark, 1995, 2002) of probable maximum precipitation (PMP), the original estimate of the PMF of 240 cumecs (Wessex Water Authority, 1982) was increased to $500+$ cumecs at the Bruton dam site and was eventually used in order to make the original structure, built in 1984, comply with the Reservoir Safety Act. It was increased in capacity and made safe from breaching and a life threatening flood downstream (Environment Agency, 2006).

Table 4 shows the estimates of peak discharge for the top seven events. Although the actual values of the peak discharge may be in error, and there is no way to get an exact answer, the frequency of flooding remains robust.

Figure 8 shows these results plotted on a Logarithmic-modified Gumbel scale. Several points are of vital importance. Traditionally many studies use a linear scale for either rainfall or riverflow, the result is an exponential relationship which at some point must change to a much lower gradient. The present analysis does not have this problem since the modified Gumbel scale goes up to the probable maximum flood (PMF) or precipitation (PMP) with the restriction that the best estimates of the events will always plot as a straight line. Figure 8 shows the estimate of bankfull discharge with a rarity of around 1.1 years, within the range of 1.1 - 4 years (Leopold et al., 1964; Williams, 1978; Edwards et al., 2019) most common for alluvial and gravel bed rivers. Also shown on Figure 8 is the threshold of flooding, the seven highest floods, and an estimate of the PMF based on the envelope curve of Allard et al. (1960), enhanced by Acreman (1989) and called the Extreme Catastrophic Flood (ECF). According to Allard et al. (1960), it will commonly occur on steep, wet, upland catchments such as the Eden at Appleby. 


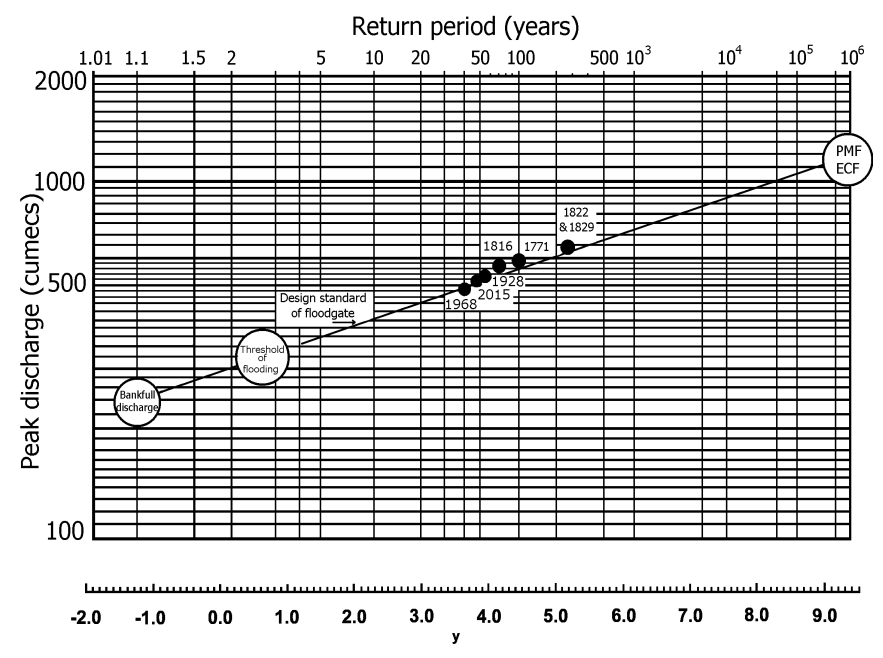

Figure 8. Flood frequency analysis for the river Eden at Appleby.

Application of the Revitalised rainfall runoff method of the Flood Estimation Handbook (Rev FEH) gave a value for the 1.1-year flood of $150 \mathrm{~m}^{3} \cdot \mathrm{s}^{-1}$. For this result to be correct the roughness factor in the Eden would have to be 0.072 a value which is simply not credible as compared with a value of 0.043 . An $n$ value of 0.072 is for a channel with large boulders and other restrictions such as overhanging vegetation. Furthermore, as shown in Chow (1959) the n value tends to decrease with increasing stage up at least to bankfull stage.

In addition to the results in Table 4 there are the estimates of bankfull discharge of 252 cumecs, and an estimate of the threshold of reported flooding of once every three years. A depth of water along The Sands of about $0.5 \mathrm{~m}$ gives a discharge of $337 \mathrm{~m}^{3} \cdot \mathrm{s}^{-1}$. At the very extreme flood level the Extreme Catastrophic Flood (ECF) was calculated:

$$
\log \mathrm{ECF}=-0.5686 \log A+1.9820
$$

where the ECF is cumecs per $\mathrm{km}^{2} . A=$ catchment area. This equation is best applied to steep wet catchments of which the upper part of the Eden is very representative. The result gives an ECF $=1185 \mathrm{~m}^{3} \cdot \mathrm{s}^{-1}$. Trials with estimates of PMP show that the FEH $(\mathrm{IOH}, 1999)$ cannot reproduce a flood of this size whereas those produced using estimates of PMP by Clark (2002) get within 170 cumecs of the ECF. A higher result would be expected with a full hydrograph analysis since the rainfall intensity is not uniform during a PMP event.

All the evidence of floods must broadly fit in linear fashion on the Log-modified Gumbel scale as shown in this paper and advocated by the author for over 20 years. From the eye witness accounts by people of long residency an estimate of the frequency of bankfull discharge is $1.1-1.5$ years. Using a frequency for bankfull discharge of 1.1 years and an ECF of 1185 cumecs as a minimum value, gives a flood frequency equation:

$$
\log Q=0.0630 y+2.4820
$$

Application of this equation to a flood level of $0.8 \mathrm{~m}$ above bankfull gives a return period of 8 years. This is the level of the floodgate at St Lawrence Bridge. 


\section{Estimating the Return Period of the December 2015 Flood Using Hydrometeorology}

As an example of cross validating estimates of flood rarity, the author has developed a method based on rainfall frequency and soil moisture deficit (SMD) (Clark, 2007, $2018+$ online material). In essence, the rarity of a flood is equal to the joint probability of the flood producing rainfall and the threshold SMD. In terms of return period $(1 / \mathrm{p})$ the equation becomes:

$$
\text { Rp flood }=\mathrm{Rp} E R \times \operatorname{Rp} \mathrm{SMD}_{\text {Threshold }}
$$

where:

$\mathrm{Rp} E R=$ return period of the effective rainfall $=(\mathrm{R}-\mathrm{SMD})$.

$\mathrm{Rp} \mathrm{SMD}$ Threshold $=$ return period of the SMD at which runoff takes place.

Rainfall frequency follows the methodology in Clark (2018, 2019). During the winter period when the SMD (soil moisture deficit) is nil the equation reduces to:

$\mathrm{Rp}$ flood $=\mathrm{Rp}$ ER or simply storm rainfall.

Figure 3 and Figure 4 show areal distribution of rainfall for the $4^{\text {th }}$ and $5^{\text {th }}$ December. The storm started at $20.33 \mathrm{hrs}$ UTC on $4^{\text {th }}$ December. Peak discharge at Appleby was at 20.30 UTC on $5^{\text {th }}$ December and allowing one hour for rainfall to enter the main river gives an effective storm duration of 23 hours. The nearest TBR is at Scalebeck $7 \mathrm{~km}$ SSW of Appleby. Rainfall in this time period was 140.4 $\mathrm{mm}$ with a total of $189 \mathrm{~mm}$ for the two rainfall days. From Figure 3 and Figure 4, the catchment average rainfall for the two days was the sum of $39.9 \mathrm{~mm}$ and $64.7 \mathrm{~mm}$. Scaling this rainfall in the effective rainfall time of 23 hours gives: $(140.4 / 189) \times(39.9+64.7)$ or $78 \mathrm{~mm}$ in 23 hours. Box 1 shows the detailed calculations of areal rainfall frequency.

BOX 1 Rainfall frequency estimation.

$24 \mathrm{hr}$ PMP $=475$ mm (Clark, 2002, map showing 24 hr Probable Maximum Precipitation for Britain).

$1 \mathrm{hr}$ PMP = $160 \mathrm{~mm}$ (Clark, 2009, estimated from storm maximisation).

For durations $1-24 \mathrm{hr}$ can be calculated using the logarithm of the duration and rainfall depth $R=228.225 \log D+160$ where $D=$ duration (hours).

Therefore $23 \mathrm{hr} \mathrm{PMP}=470.8 \mathrm{~mm}$.

An estimate of the 2-year rainfall is obtained from the FEH (IOH, 1999).

23 hour 2-year areal rainfall $=44.1 \mathrm{~mm}(\mathrm{FEH}$ CDROM). This estimate includes an areal reduction factor which is the ratio of point to areal rainfall for a given storm duration and area.

The areal reduction factor varies according to storm rarity (Clark, 2007, 2012).

Areal reduction factor for $23 \mathrm{hr}$ PMP $=0.595$ (Clark, 2012).

Rainfall frequency varies according to the time of year. The seasonal correction factor is obtained from Kjeldsen et al. (2005):

Seasonal correction factor ReFH (Kjeldsen et al., 2005) $=0.84$.

The storm took place during winter so the seasonal areal $23 \mathrm{hr} \mathrm{PMP}=470.8 \times$ $0.84 \times 0.595=235.3 \mathrm{~mm}$.

Seasonal areal $2 \mathrm{yr} 23 \mathrm{hr}$ rainfall $=44.1 \times 0.84=37.0 \mathrm{~mm}$. 
The modified Gumbel reduced variate equation (Clark, 2015):

$$
y=\left[(-\ln \ln (1-1 \div T)-3.3842) \times 1.09348 \times T^{-0.046518}\right]+3.3842
$$

where $T=$ return period.

y. $2 \mathrm{yr}=0.1891 ; y: 10^{6} \mathrm{yr}=9.3826$.

The logarithm of the two depths of rainfall, $37 \mathrm{~mm}$ and $235.3 \mathrm{~mm}$ are regressed with their respective $y$ values of 0.1891 and 9.3826:

Thus the rainfall frequency equation: $\log R=0.0873 y+1.5516$.

Thus for $78 \mathrm{~mm}$ in 23 hours $y=3.9002$.

The value of 3.9002 is used with Equation (2) to yield its value of $T$ or return period.

Return period $=53$ years.

End of Box 1.

This compares with a return period of 47 years from the historic flood frequency analysis. The uncertainty of this estimate depends on the measurement of rainfall. Although the rainfall intensity was low there can be an underestimate of $5 \%$ which would give a return period of 59 years. On the other hand, the value of PMP may be an underestimate in the higher parts of the catchment and this would lead to a reduction in the return period. Overall, the event of December 2015 has an estimated return period of about 50 years.

The uncertainty in the flood frequency analysis has been reduced by the close agreement of the bankfull discharge calculated from channel dimensions and assigned a rarity of 1.1 years, the seven historic floods, the threshold of flooding from photographic evidence and discharge calculation of the 1903 flood event, and an estimate of the PMF which is consistent with the nationwide survey of historic floods (Allard et al., 1960) and brought up to date by Acreman (1989). Where these 10 estimates are correlated with their estimated frequency the result is $r=0.99$ sig. $0.01 \%$. By itself this does not constitute proof of accuracy, but shows that when flood estimates produced in different ways are related to their frequency there is a high degree of consistency. The hydrometeorological estimate of the rarity of the flood producing conditions would need a $9 \%$ reduction in the peak discharge of the 2015 flood to produce an exact match with the flood frequency equation. If this were correct then the threshold of flooding declines to a frequency of 1 in 4 years. The low level of uncertainty is shown by the estimates of bankfull discharge, threshold of flooding and the PMF being shown as open circles on Figure 8.

\section{Human Response to the Flood Hazard at Appleby}

It was Burton et al. (1968) who showed that control works are usually implemented when floods take place once every three years, so with such a long flood history it is instructive to see how people have coped over the past 250 years. Because of the frequent floods, a scheme giving protection for the 1 in 100 year flood might be expected, especially as the number of properties affected has exceeded 200 in 1928 and 100 in 1968. Smith \& Tobin (1979) describe previous 
responses. In 1907 there was a proposal to dredge the river Eden from just above to below the town. Flood walls were planned in the 1930's while in the mid 1970's a more comprehensive scheme of dredging and bank grading at a cost of $£ 120,000$ considered. None of these schemes were implemented and while Smith $\&$ Tobin suggested cost as the main reason, when it is inflated to 1984 prices an estimate of $£ 0.4 \mathrm{M}$ is produced. This is only $36 \%$ of the cost of the 1984 Bruton flood alleviation scheme where the number of affected properties was less than 50. A new flood wall and floodgate (Figure 9) were installed in 1998. However, in comparison with the analysis presented here, it only has a design standard of about 1 in 10 years. Furthermore, the hydrostatic pressure from the Eden during high flow leads to backflow up road drains, making the scheme rather ineffective. During the author's visit to Appleby in May 2019, there was evidence of sand bags close by doorways. In some cases refuse from the last flood in 2015 was still left outside. Although there is a flood warning system with an alarm given, it is still dependent upon residents taking personal action, day or night to avoid damage to personal belongings and the interior fabric of their homes. The question then becomes what do they do if they decide to go on holiday?

\section{Discussion}

Historically villages and small towns have had little or no consistent flood information available. It has been the existence of several good local newspapers in a fairly remote part of England that has been the main source of information. The results show that notable floods occur about once every three years. Elsewhere this regularity of flooding has been enough to prompt significant remedial works where the frequency of positive certainty and adopted remedial works is about 1 in 2.5 years. Yet in spite of the Water Act of 1973 and subsequent legislation a good level of protection has not been provided for the town of Appleby. The reasons for this are more complicated than appears at first sight. One reason is that the townsfolk have largely adapted to the hazard by means of flood proofing and a warning system. Another may be a resignation to the problem which, apart from events like 1968, 2005, and 2015, do not cause huge damage

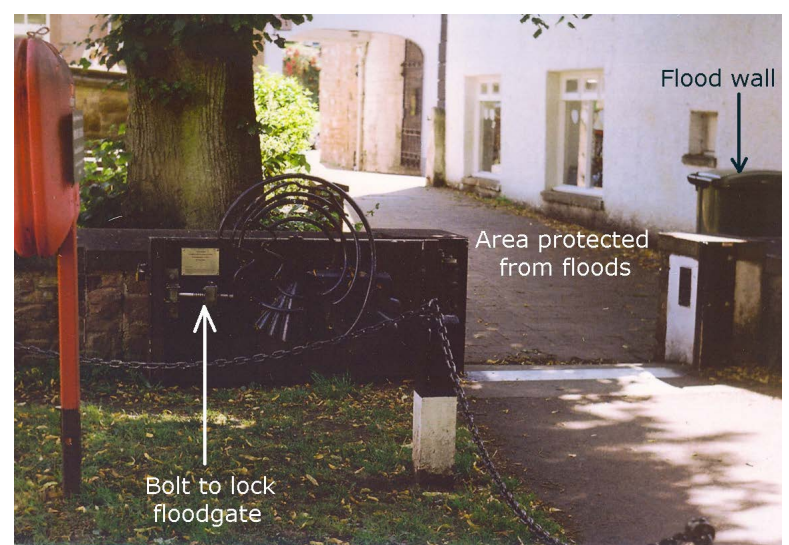

Figure 9. Moveable flood barrier close to the west bank of the Eden at Appleby. 
and are not perceived as life threatening: for example the 2004 flood at Boscastle in Cornwall brought swift engineering works at considerable cost, whereas Appleby has experienced many more flood events.

It may be that an estimated rarity of 1 in 50 now assigned to the 2015 flood could lead to an economic justification for a better level of protection. It remains to be seen whether or not the effects of the rather inadequate self operated schemes have to be taken into account when a cost benefit analysis is carried out. But with an aging population, a flood stress-free lifestyle would be very welcome. A realistic identification of the flood frequency at Appleby is the first step towards this goal.

\section{Conclusion}

Taking into account a change in bridge cross section, an analysis of 249 years of recorded flood events, together with the use of hydraulic calculations to estimate the peak discharges, has allowed an estimate of the flood frequency for the river Eden at Appleby. To some extent, the result is validated by estimates of the bankfull discharge and the PMF. Land use changes in at least the upper part of the catchment have been minimal which largely avoids problems of non-stationarity in the record. However, changes may take place in the future of land use and climate. Further cross validation of flood rarity was achieved using the joint probability method. Another check related to the threshold of flooding of properties which is about 1 in 3 years. This agrees well with the detailed records of the more common flood events. Significantly the highest five events all took place before 1930, suggesting, that all else equal, very serious floods are now overdue, and that any interpretation of these future events must be tempered by what the historic record shows. Recent attempts by the Environment Agency to alleviate flooding at Appleby by means of flood gates have a low standard of protection. With over 100 domestic and commercial properties at risk, and with a resident population of just over 3000, many of whom live in the flood prone area, serious consideration should be given to producing a flood alleviation scheme with a high standard of design.

\section{Acknowledgements}

The author would like to thank Darren Rogers for his collection of flood reports and encouragement in this work. Also to Vivienne Gates who provided information on the 1968 flood. The rainfall data came from the UKMO archive at Exeter and the Environment Agency for which the author is grateful.

\section{Conflicts of Interest}

The author declares no conflicts of interest regarding the publication of this paper.

\section{References}

Acreman, A. C. (1989). Extreme Historical UK Floods and Maximum Flood Estimation. 
Water and Environment Journal, 3, 404-412.

https://doi.org/10.1111/j.1747-6593.1989.tb01546.x

Allard, W., Glasspole, J., \& Wolf, P. O. (1960). Floods in the British Isles. Proceedings of the Institution of Civil Engineers, 15, 119-144. https://doi.org/10.1680/iicep.1960.11901

Burton, I. R., Kates, R. W., \& White, G. F. (1968). The Human Ecology of Extreme Geophysical Events. Natural Hazard Research Working Paper No. 1, Toronto: FMHI Publications.

Chow, V. T. (1959). Open Channel Hydraulics. New York: McGraw Hill.

Clark, C. (1995). New Estimates of Probable Maximum Precipitation in South-West England. Meteorological Applications, 2, 307-312. https://doi.org/10.1002/met.5060020403

Clark, C. (1983). Discussion of Gumbel's Extreme Value 1 Distribution: A New Look. Journal of Hydraulic Engineering, 109, 644-646. https://doi.org/10.1061/(ASCE)0733-9429(1983)109:4(645.3)

Clark, C. (1999). The Great Flood of 1768 at Bruton, Somerset. Weather, 54, 108-113. https://doi.org/10.1002/j.1477-8696.1999.tb06436.x

Clark, C. (2002). Rainfall Estimates (PMP) in Great Britain. International Water Power \& Dam Construction, 54, 18-26.

Clark, C. (2007). Flood Risk Assessment Using Hydrometeorology and Historic Flood Events. International Water Power \& Dam Construction, 59, 22-30.

Clark, C. (2009). The Use of Local Data in Predicting and Estimating Extreme Floods. Water, Environment, Energy and Society (WEES 2009), Vol II Statistical and Systems Analysis Techniques (pp. 635-646). Mumbai: Allied Publishers.

Clark, C. (2012). Spillway Design Flood and Flood Volume Estimated Using the New Guide to Flood Estimation. In T. S. W. Wong (Ed.), Flood Risk and Flood Management (pp. 219-255). New York: Nova Science.

Clark, C. (2013). Measurements of Actual and Pan Evaporation in the Upper Brue Catchment UK: The First 25 Years. Weather, 68, 200-208.

https://doi.org/10.1002/wea.2090

Clark, C. (2014). The Great Flood of 1726 at Bruton, Somerset. Weather, 69, 249-253. https://doi.org/10.1002/wea.2272

Clark, C. (2015). Downward Trend in Two Rural Temperature Records in Somerset, UK. Weather, 70, 280-284. https://doi.org/10.1002/wea.2512

Clark, C. (2018). The Storm and Flood of 13 May 1906 at Mells, Somerset, UK. Weather 73, 109-115. (+ Online Supporting Material) https://doi.org/10.1002/wea.3230

Clark, C. (2019). How Rare Is That Storm or Flood? Weather, 74, 432-436. (+ Online Supporting Material) https://doi.org/10.1002/wea.3452

Clark, C., \& Pike, W. S. (2007). The Bruton Storm and Flood after 90 Years. Weather, 62, 300-305. https://doi.org/10.1002/wea.142

Cumbria County Council (2016). Appleby in Westmorland: Flood Investigation Report (51 p). Carlisle: Cumbria County Council.

Edwards, P. J., Watson, E. A., \& Wood, F. (2019). Towards a Better Understanding of Recurrence Intervals, Bankfull, and Their Importance. Journal of Contemporary Water Research \& Education, 166, 35-45. https://doi.org/10.1111/j.1936-704X.2019.03300.x

Environment Agency (2006). Bruton Flood Storage Reservoir: Report on Hydraulic and Hydrological Studies (43 p + Appendix 9 p). Exeter: Black \& Veatch.

Garret, W. (1818). An Account of the Great Floods in the Rivers Tyne, Tees, Wear, Eden Etc. in 1771 and 1815 (47 p). Newcastle: Emerson Charnley. 
IOH (1999). Flood Estimation Handbook (5 Vols). Wallingford: IOH.

Kjeldsen, T. R., Stewart, E. J., Packman, J. C., Fowell, S. S., \& Bayliss, A. C. (2005). Revitalisation of the FEH/FSR Rainfall-Runoff Method. Joint DEFRA/EA Flood and Coastal Erosion Risk Management R+D Programme. R+D Technical Report. FD 1913/TR.

Leopold, L. B., Wolman, M. G., \& Miller, J. P. (1964). Fluvial Processes in Geomorpholo$g y(522 \mathrm{p})$. New York: Freeman.

Macdonald, N. (2012). Reassessing Flood Frequency for the River Trent through the Inclusion of Flood Information since AD 1320. Hydrology Research, 44, 215-233. https://doi.org/10.2166/nh.2012.188

Macdonald, N., \& Black, A. R. (2010). Reassessment of Flood Frequency Using Historical Information for the River Ouse, York. Hydrological Sciences Journal, 55, 1152-1162. https://doi.org/10.1080/02626667.2010.508873

Macdonald, N., Black, A. R., Werrity, A., \& McEwen, L. J. (2006). Historical and Pooled Flood Frequency Analysis for the River Tay at Perth Scotland. Area, 38, 34-46. https://doi.org/10.1111/j.1475-4762.2006.00673.x

Mannex, P. J. (1851). History, Topography, and Directory of Westmorland. London: Beverley.

Reed, D. W., \& Bayliss, A. C. (2001). The Use of Historical Data in Flood Frequency Estimation (87 p). Wallingford: MAFF.

Rogers, D. (2019). Maulds Meaburn Historical Floods. http://www.mauldsmeaburnweather.co.uk/floods.htm

Smith, K., \& Tobin, G. A. (1979). Human Adjustment to the Flood Hazard. London: Longman.

Todd, B., \& Black, A. (2010). Use of historic sources in flood estimation. Circulation, 104, 4-6.

UKMO (1977). Average Rainfall 1941-1970 Northern Britain.

Watkins, S., \& Whyte, I. (2008) Extreme Flood Events in Upland Catchments in Cumbria since 1600: The Evidence of Historical Records. North West Geographer, 8, 33-41.

Wessex Water Authority (1982). Bruton Flood Alleviation Scheme: Report. Bridgwater: Rendle Palmer \& Tritton.

Williams, G. P. (1978). Bank-Full Discharge of Rivers. Water Resources Research, 14, 1141-1154. https://doi.org/10.1029/WR014i006p01141

Williams, A., \& Archer, D. (1999). The Use of Historical Flood Information in the English Midlands to Improve Risk Assessment. Hydrological Sciences Journal, 47, 57-76.

https://doi.org/10.1080/02626660209492908 